\title{
VIOLÊNCIA, CRIME E POLÍCIA: o que os favelados dizem quando falam desses temas?
}

\author{
Luiz Antonio Machado da Silva* \\ Márcia Pereira Leite**
}

Resumo: O artigo baseia-se em duas pesquisas qualitativas em favelas cariocas, especialmente em uma de suas atividades, aproximadamente 50 horas de dinâmica com 15 grupos focais (envolvendo 150 moradores de mais de 40 favelas). Designou-se de "coletivos de confiança" os grupos focais compostos a partir de relacionamento anterior dos participantes com algum dos pesquisadores, capaz de, através do conhecimento pessoal, gerar alguma confiança prévia. Pensada com vistas a minimizar os prováveis efeitos de uma "lei do silêncio" imposta pelos agentes da violência nessas localidades, esta forma de recrutamento demonstrou ter sido adequada. $\mathrm{O}$ texto analisa os enunciados colhidos durante os debates, claramente concentrados nas diferentes modalidades de presença e atuação dos bandos de criminosos e das forças policiais nas favelas cariocas. Sustenta que, menos que questionar a violência criminal e policial como um todo, eles expressam intensa preocupação com algumas de suas manifestações, aquelas que impedem o prosseguimento das rotinas diárias. Sem ser diretamente tematizado, este é o horizonte de atenção que organiza todo o discurso crítico "para fora" das favelas, bem como as atitudes e condutas nos locais de moradia. Os autores avançam um pouco mais, argumentando que, em suas descrições e denúncias, os moradores demonstram não lidar da mesma maneira com todas as formas de desestabilização de suas rotinas, evitando homogeneizar os responsáveis. Assim é que, de um lado, a violência deflagrada durante as famosas "operações" policiais e sempre presente na arbitrariedade da conduta regular

\footnotetext{
* Professor titular do Iuperj/Ucam e professor associado do IFCS/UFRJ. E-mail: 1machado@ iuperj.br

** Professora adjunta do DCS/PPCIS/UERJ. E-mail: marciaspleite@uol.com.br
}

Artigo recebido em 24 jul. 2007 e aprovado em 25 set. 2007. 
desses agentes aparece associada ao seu caráter quase totalmente imprevisível. De outro lado, quando se trata da violência envolvida nas práticas dos traficantes, com os quais os moradores são obrigados a compartilhar o mesmo território, há muitos relatos de tentativas (bem e mal/sucedidas) de redução da imprevisibilidade do fluxo da vida local. Isto ocorre por meio do ajustamento das condutas a um cálculo - inviável e/ou ineficaz no caso da ação policial dos riscos envolvidos nesta convivência forçada. Este, tornando "administrável" uma pequena porção da violência na localidade, permite reabsorvê-la como a parte "extraordinária" das rotinas "ordinárias".

Palavras-chave: violência, crime, polícia, rotina, risco, sociabilidade.

\section{Introdução}

Este artigo analisa os relatos de moradores de favelas cariocas sobre a violência que vivenciam no cotidiano dessas localidades diante das diferentes modalidades de presença e atuação dos bandos de criminosos e das forças policiais. Sustenta que eles enquadram estas questões a partir de uma preocupação constante com as interrupções na estabilidade das rotinas diárias provocadas pelas freqüentes explosões de violência. Sem ser diretamente tematizado, este é o horizonte de atenção que organiza todo o seu discurso crítico "para fora" das favelas, bem como suas atitudes e condutas nos locais de moradia. O texto avança um pouco mais, argumentando que, em suas descrições e denúncias, os moradores demonstram não lidar da mesma maneira com todas as formas de desestabilização de suas rotinas, evitando homogeneizar os responsáveis. Assim é que, de um lado, a violência deflagrada durante as famosas "operações" policiais e sempre presente na arbitrariedade da conduta desses agentes aparece associada ao seu caráter quase totalmente imprevisível. De outro lado, quando se trata da violência envolvida nas práticas dos traficantes, com os quais os moradores são obrigados a compartilhar 
o mesmo território, há muitos relatos de tentativas (bem e malsucedidas) de redução da imprevisibilidade do fluxo da vida local. Isto ocorre por meio do ajustamento das condutas a um cálculo dos riscos envolvidos nesta convivência forçada. Este, tornando "administrável" uma pequena porção da violência na localidade, permite reabsorvê-la como a parte "extraordinária" das rotinas "ordinárias".

O material empírico que sustenta a elaboração do argumento é resultante de duas pesquisas qualitativas recentes sobre violência em favelas ${ }^{1}$ e constitui-se de descrições e relatos obtidos em 15 grupos focais organizados com base em "coletivos de confiança" que envolveram 150 moradores de 45 favelas do Rio de Janeiro; ${ }^{2}$ 15 entrevistas em profundidade com moradores selecionados; e acompanhamento etnográfico em três favelas, escolhidas por serem classificadas pelos moradores e, mais geralmente, pela opinião pública, segundo diferentes modalidades de violência (uma, considerada "muito violenta", com tráfico ostensivamente armado e recorrentes disputas do território, além de possuir longa tradição de ação coletiva; outra, considerada "calma", por não sediar "bocas de fumo"; a terceira dominada pelo que atualmente se designa de "milícia". ${ }^{3}$ Designou-se de "coletivos de confiança" os grupos focais com moradores de favelas, realizados em salas alugadas fora das favelas e compostos a partir de relacionamento anterior dos participantes com algum dos pesquisadores, capaz de, através do conhecimento pessoal, gerar alguma confiança prévia. Esses cuidados foram considerados necessários como forma de favorecer uma comunicação aberta e franca, devido ao caráter delicado das questões que se previa iriam surgir na dinâmica das sessões. Seu objetivo era minimizar a chance de bloqueio representada pela "lei do silêncio" derivada do clima de medo e insegurança nas favelas. Os resultados obtidos confirmam a adequação do procedimento. Cumpre acrescentar que, a fim de não impor de antemão temas específicos, os moderadores sempre iniciaram as conversas perguntando "como 
é a vida nas favelas" e estimularam os debates tendo em mente um leque temático previamente estabelecido. Esta dinâmica propiciou o confronto de narrativas, com as suas respectivas avaliações cognitivas e morais, sobre acontecimentos diversos, sendo extremamente rica na produção de evidências relevantes. ${ }^{4}$

Evidentemente, os autores não pretendem ter fundamentado seu argumento em uma reconstrução exaustiva de todo o material coletado. A intenção do presente artigo é apenas explorar o sentido geral das descrições e relatos dos moradores, oferecendo uma possibilidade de interpretação - que pode ser tomada, ao mesmo tempo, como hipótese e plano de trabalho - sobre suas percepções a respeito da violência policial e criminal e os significados que atribuem às suas próprias condutas para lidar com a volência nos locais de moradia e no espaço público.

\section{Uma crítica da representação dominante}

Para a interpretação mais largamente difundida no Rio de Janeiro, as favelas seriam o território da violência e a população ali residente conivente com seus agentes, os traficantes de drogas. $\mathrm{O}$ discurso público dominante apreende e explica a "violência urbana" 5 através da "metáfora da guerra" (Leite, 2007b) e dos "mitos" que lhe são associados, variavelmente presentes no entendimento de diversos atores: cidade legal versu. cidade ilegal, Estado dentro do Estado, conivência dos moradores de favelas com os criminosos, banalização da violência, etc. Esses "mitos" sustentam grande parte do pacote interpretativo ${ }^{6}$ que estrutura, atualmente, o "problema da violência" no Rio de Janeiro e o horizonte das propostas e medidas para seu controle e redução. Entretanto, como se verá, uma análise a partir das pesquisas mencionadas permite submetê-los à crítica. Considerando inevitável que esta discussão permeie o presente trabalho, um comentário inicial facilitará seu entendimento. Comecemos, portanto, por apresentá-lo. 
Os "mitos" acionam estereótipos longamente maturados que questionam a participação do conjunto dos favelados na moralidade hegemônica, assim como a postura ética dos moradores desses territórios. Reeditam, aggiornatta, a representação das classes perigosas (Chevalier, 1984; Guimarães, 1981; Zaluar, 1994; 1985), agora deslocada do campo propriamente político relativo à apropriação do aparelho de Estado para o terreno sociocultural do perigo envolvido no descumprimento de regras de conduta contidas na moral dominante. Os moradores de favelas são tomados como cúmplices dos bandos de traficantes, porque a convivência com eles no mesmo território produziria aproximações de diversas ordens - relações de vizinhança, parentesco, econômicas, relativas à política local, etc. - e, assim, um tecido social homogêneo que sustentaria uma subcultura desviante e perigosa. Esta, por sua vez, fundamentaria a aceitação e a banalização do recurso à força, o que terminaria por legitimar e generalizar a chamada "lei do tráfico". Em conseqüência, os moradores de favelas estariam recusando a "lei do país" ao optarem por um estilo de vida que negaria as normas e valores intrínsecos à ordem institucional. Uma forte conivência marcaria, portanto, as relações dos moradores de favelas com as redes criminosas sediadas nessas localidades, levando-os a buscar sua proteção e apoio, bem como a protegê-las da polícia.

No caso específico dos jovens, mais do que as ambigüidades de uma conivência que não implica engajamento, haveria proximidade, idealização do estilo de vida dos traficantes e adesão ativa. $\mathrm{Na}$ interpretação dominante, a juvenilização dos bandos de traficantes, que parece ser uma tendência real (Oliveira, 2007; Soares et al., 1996; Zaluar, 2004; 1994), tem sido associada às proteções ao menor, categoria jurídica utilizada pelo Estatuto da Criança e do Adolescente e por ele protegida de várias formas, inclusive por um tratamento penal mais brando. Os criminosos estariam, portanto, instrumentalizando este documento legal em benefício de suas atividades. 
Mesmo sabendo-se que a grande maioria não integra as quadrilhas, os jovens favelados têm sido percebidos e tratados como em permanente risco de a elas aderir, posto que as atividades ligadas ao tráfico de drogas seriam muito atrativas entre os estratos inferiores - combinando, assim, economicismo e preconceito. Neste ponto, é interessante observar a porosidade da representação dominante: ela é capaz de incorporar, absorvendo - e distorcendo o que muitas vezes é uma crítica - as constantes referências à sedução por bens de consumo inacessíveis a este segmento populacional e ao fascínio pelas armas, elemento da construção de uma masculinidade "guerreira" (Cecchetto, 2004; Zaluar, 2004; Soares, 2000).

Aqui talvez resida o mais claro exemplo do encontro entre representação, construção de problemas públicos e políticas de intervenção. Com efeito, as idéias de cumplicidade com os criminosos são em boa parte sustentadas, reproduzidas e objetivadas pelas próprias políticas sociais e/ou ações filantrópicas destinadas aos moradores de favelas em geral e, especialmente, aos seus segmentos mais jovens. À sua orientação claramente focalizada e compensatória é adicionada uma filosofia justificadora que penaliza a clientela, sempre pensada como potencialmente criminosa. Os programas passam a ser formulados e implementados em um viés repressivo/ preventivo, como uma espécie de ampliação dos instrumentos de controle social, visando afastar as categorias sociais "vulneráveis" ou "de risco" das "tentações" da carreira criminal. Dessa maneira, cria-se algo como o "criminoso em potencial". Moraes (2005), analisando as políticas públicas para a juventude, chega a referirse à "policialização" das mesmas, aproximando-se dos trabalhos de Wacquant sobre o "Estado policial" (Wacquant, 2001a).

No mesmo passo, este pacote interpretativo orienta as práticas extra-oficiais dos policiais no tratamento dos moradores de favela, e implicitamente, delega a eles as decisões a respeito de quando, como e contra quem adotar medidas repressivas mais diretas e duras, 
liberando-os para ir além do uso da "força comedida" que é sua atribuição institucional (Brodeur, 2004). É desnecessário mencionar o enorme peso da cor da pele e da juventude na tipificação desses objetos preferenciais. ${ }^{7}$

Essa representação das favelas como uma espécie de subcultura, inclusive pela ciência social, nada tem de recente(Valladares, 2005). O que parece novo é que agora não se trata de basear este entendimento, como antes, na desorganização social e no atraso cultural dessas localidades, mas de associá-las diretamente ao crime violento. Isso aprofunda e radicaliza o dualismo que marca a imagem da cidade, cujo melhor exemplo no jornalismo contemporâneo é Ventura (1994). Sua contraface são os "mitos" relativos à ausência do Estado nas favelas, que seriam dominadas por um poder paralelo constituído pelos bandos de traficantes, a partir dos quais se constrói a metáfora da guerra. É desnecessário notar que esta versão frouxa da idéia de "dualidade de poder" que foi utilizada em certas definições de momentos revolucionários desconhece as inúmeras evidências de presença dos aparelhos de Estado (tanto do Executivo quanto do Legislativo) e seus agentes nas favelas. Mais importante é sublinhar que a idéia de um "Estado dentro do Estado" depende em grande parte de duas operações cognitivas. De um lado, da transformação em conivência generalizada do que é submissão dos moradores, pela força, às necessidades logísticas dos bandos de traficantes. De outro lado, do desconhecimento de que esta submissão forçada não altera sua firme adesão à ordem institucional, que pode ser claramente percebida tanto nas descrições de ações efetivamente realizadas quanto de disposições e atitudes subjetivas. ${ }^{8}$

\section{Breve comentário sobre os pressupostos}

Alguns pressupostos e escolhas metodológicas circunscrevem a perspectiva analítica adotada neste artigo. A maciça evidência 
do caráter contexto-dependente das práticas e representações na modernidade tardia (que não contraria a "globalização") não favorece as grandes totalizações, sejam elas de natureza teóricoformal ou histórica. Parecem mais adequadas as generalizações que permaneçam no limite da experiência vivida, enfatizando a contingência, a variedade e a inconsistência dos laços entre as diferentes situações e nas práticas dos atores.

Sem negar sua relevância nem pretender uma discussão pormenorizada, os autores consideram que boa parte do pensamento social brasileiro adota um paradigma de análise que problematiza as tendências de nosso desenvolvimento histórico a partir de uma leitura contrafactual prisioneira da "comunidade imaginada do povonação" (Anderson, 1983). Com efeito, o Brasil constituiu-se como parte do desenvolvimento das sociedades capitalistas ocidentais sem, entretanto, conformar-se ao que corresponde à auto-imagem das repúblicas européias. Entretanto, uma perspectiva muito difundida, que incorpora o Brasil à história do Ocidente de forma contrafactual, tende a conduzir a uma análise das relações Estado-sociedade a partir do ângulo de sua ambigüidade, carência ou incompletude sociocultural e política. Nesta linha, é pela inconsistência, pela falta ou pelo desvio que o Brasil se converte em caso particular de um tipo mais geral, e a auto-imagem européia em modelo ideal-normativo de compreensão. Uma alternativa a esta leitura contrafactual envolveria reconhecer e priorizar analiticamente o modo específico de constituição das diferentes formações sociais - no caso presente, a particularidade da experiência brasileira.

Gramsci (1976), pensando a ação política de classe, recupera sua dimensão histórica introduzindo uma distinção analítica importante entre as formações "ocidentais" e as "orientais", em que o Estado é "tudo" (referindo-se à centralização da sociedade política) e a sociedade civil, "gelatinosa". Mais recentemente, a literatura pós-colonial questionou a compreensão do Estado 
com base no que conformaria o modo específico de constituição e desenvolvimento dos Estados-nação europeus (centralização do poder, monopolização da violência, afirmação do princípio da territorialidade da obrigação política, universalização da cidadania), que é tomado explicita ou implicitamente como modelo para outros países, outras culturas, outras temporalidades. Assim é que, por exemplo, Das e Poole (2004) apoiam-se em Foucault para sugerir uma antropologia política que explore as "margens do Estado". 9 Referem-se não a fronteiras geográficas, áreas em que o Estado ainda não teria penetrado completamente e que não regularia, ou o faria apenas parcialmente, mas a territórios, populações, práticas que são produzidos pela dinâmica do próprio Estado moderno. Deste ângulo, as "margens do Estado" deveriam ser vistas como variando segundo sua morfologia interna. Ou, como sustenta Asad (2004, p. 280), de acordo com "as diferentes maneiras de determinar pertencimento e inclusão, dentro e fora, a lei e a exceção". Assim, o funcionamento do Estado nas "margens" vincula-se, entre outros aspectos, aos critérios efetivos de cidadania e às diferentes modalidades de aplicação da lei em casos específicos, às relações estabelecidas no tempo e no espaço - portanto sempre datadas e situadas - entre as instituições estatais e seus agentes com os diferentes segmentos da população que habita o território nacional, bem como à percepção destes acerca do funcionamento institucional.

A sugestão é interessante para a análise dos relatos disponíveis. Eles permitem entrever como os moradores de favela constroem seu entendimento da sociabilidade em suas localidades, suas formas de lidar com os perigos e riscos que identificam, e os modos como analisam sua inserção institucional. É possível apreender essas relações como se desenhando com base em uma equação centro-periferia que não tem no espaço (físico e social) seu vetor exclusivo nem determinante - embora a constituição (geográfica e simbólica) dos territórios da cidade seja uma das dimensões. Da perspectiva sugerida, a polarização centro-periferia não é unívoca, 
pois se estabelece segundo fluxos e mediações diversas, situando e qualificando variavelmente o peso da regulação estatal em relação a diferentes territórios e populações. Deste ponto de vista, seria preciso reconhecer o caráter contexto-dependente das formas de coordenação das ações entre os diferentes atores, sem que isso implique negar a unidade de nossa integração social.

Especificamente no que diz respeito à questão da cidadania, estas considerações aproximam-se do que Lautier (1997, p. 87) denomina "cidadania de geometria variável" para indicar que é característico da sociedade brasileira (e de outros países) o "abandono do postulado que define a própria noção de cidadão: a univocidade da cidadania e, portanto, do conjunto de direitosdeveres, sobre um dado território nacional". Desnecessário dizer que a noção de geometria variável corresponde a uma cidadania que se modifica segundo hierarquias de poder tácitas mas informalmente consolidadas, variáveis e sempre situadas, com forte influência sobre o entendimento e a prática das regras institucionais. Ela admite que nem sempre a linguagem dos direitos é hegemônica e que, quando isso ocorre, o conceito prático de cidadania surge diferencialmente “indexado" às situações e problemas concretos. Em síntese, no plano analítico, a cidadania não deve ser um pressuposto unívoco e universal, como nas abordagens crítico-normativas e contrafactuais anteriormente mencionadas.

A análise desenvolvida neste artigo tem como pressuposto que a "geometria variável" é constitutiva da singularidade de nossa formação social e o centro de nossa matriz cultural, secularmente falada e praticada. Esse modo de integração "fractal" entre Estado e sociedade no Brasil, se por um lado tem garantido a integridade nacional, por outro reproduz sem grandes comoções sociais uma brutal desigualdade social e política. Isto porque o conflito social no plano dos interesses e no da legitimidade - se realiza entre atores 
que se constituem como sujeitos e se reconhecem mutuamente a partir das várias hierarquias de poder inerentes à cultura brasileira.

\section{Violência policial e criminal nos relatos dos moradores}

Esta seção analisa os enunciados dos moradores sobre a presença e atuação dos bandos de criminosos e das forças policiais nas favelas cariocas. ${ }^{10}$ Examina separadamente as duas modalidades de violência abordadas nesses relatos. Em seguida, compara as diferenças no tratamento de ambas, analisando suas relações com as formas específicas de atuação dos agentes violentos nesses territórios e com os recursos disponíveis aos moradores para lidar com elas.

Como mencionado anteriormente, todas as sessões dos "coletivos de confiança" foram iniciadas de forma propositalmente vaga, com a pergunta "como é a vida nas favelas?" Mesmo assim, houve uma unânime e quase obsessiva concentração nas referências ao tópico da violência policial e criminal ${ }^{11}$ - esta quase sempre relacionada ao comércio de drogas nas localidades. O que, aliás, constitui evidência clara do equívoco de identificar a recorrência de condutas violentas nas favelas com a banalização destas práticas pelos moradores.

Sempre ressaltando que a vida nessas localidades não pode ser reduzida à violência e ao tráfico de drogas - o que denota o esforço por separar as favelas da violência - os moradores, indagados sobre como é viver em favelas, falaram de perigo, insegurança, medo:

Viver na favela é viver em linha de risco direto, é você ser alvo voluntário, um alvo constante.

...[a] vida que a gente vive no cotidiano de violência, violência física, violência moral, violência em todos os sentidos.

Você manda o garoto comprar o pão e fica pedindo a Deus para ele voltar em segurança. Ele só foi ali comprar um pão! 
Se derem um tiro e você sair correndo e entrar num beco, está arriscado morrer de uma hora para outra. Porque hoje eles [os policiais] entram nas favelas pelos lugares já estratégicos, eles já ficam escondidos debaixo de uma árvore, dentro do mato...

Se o meu filho sair, ele vai voltar? Só tem doze anos, fico preocupada. Nós, dentro da comunidade, já temos o conhecimento dos locais que são mais perigosos, eu tento fazer com que ele procure não passar por aqueles lugares.

É profissão perigo. (...) A gente está sentido que o cerco está apertando (...) Você entra, vê crianças com fuzil na mão, uma pistola... Para ir para minha igreja, para ir a outros locais na comunidade, eu tenho que passar pela 'boca' todo o dia.

Os moradores não só reconhecem que as quadrilhas de traficantes fizeram das favelas um local de violência, como deles fazem questão de se separar, como indica o uso freqüente das categorias “nós” versus "eles" (ou“"o cara", "vagabundo", "marginal”, etc.) e "lá" [na "boca de fumo"] versus "aqui" [na "comunidade"]. ${ }^{12}$ E ressaltam a mudança do estatuto da violência nas favelas devida ao tráfico de drogas, demarcando duas temporalidades e modos diversos de conduta dos criminosos.

Um quer ter o direito do outro. [Os traficantes] não querem saber se tem criança no meio da rua, não querem saber se tem um morador na rua, eles querem o quê? Tomar o território do outro. Antigamente era diferente, (...) esperavam cair a noite para poder fazer essas coisas, esperavam. Hoje em dia, o traficante senta na porta da pessoa, se droga na frente da pessoa sem ter aquele respeito. No meu tempo era proibido.

Era proibido um menor ficar na boca de fumo, era proibido um traficante passar com arma perto de um morador.

“Ô, menor, vai lá embaixo comprar uma quentinha pra mim”. A criança está passando (...) é obrigada a ir porque o cara está com 
uma arma. "Não, mas eu não posso ir porque eu vou à escola." "Não, dá tempo de você ir lá.” (...) a criança vai. Aí vai hoje por um real, amanhã a criança vai por cinco reais, depois por dez, vinte, trinta... Um fogueteiro lá, de dez anos, ganha trezentos reais por semana, só para ficar tomando conta do policial que está entrando lá embaixo. Solta fogos, trezentos reais!

Não era comum matar um morador (...), era muito difícil, quase impossível. (...) hoje em dia por qualquer coisa (...) eles matam (...). Eu ainda peguei uma parte da "velha guarda" do tráfico (...) a gente não via arma, quando falavam assim: "tem alguém morto", o morro inteiro descia para ver porque não era simples matar uma pessoa.

Se reclamar [o morador] é punido. (...) já não é mais a mesma coisa porque hoje em dia quem está no tráfico é a meninada. Antigamente as pessoas eram de mais idade, mais responsabilidade....

As pessoas sabiam que [eles] eram traficantes, eles também sabiam o papel deles, respeitavam o lugar em que moravam e até acolhiam aquele lugar para não ser invadido. Agora não, esses jovens (...) não têm medo de nada, são muito mais abusados...

Parece que eles ficam bolando que tipo de crueldade (...) vão fazer. (...) primeiro era assalto (...) agora é "micro-ondas" [inserir a pessoa em pneus de caminhão embebidos em gasolina e atear fogo] (...) para mostrar: - “olha só, aquela facção é terrível!". Eles estão mais ousados, com mais requintes de crueldade por eles serem mais jovens. (...) vão respeitar o morador com quem não têm ligação nenhuma, não cresceram? Não respeitam mesmo! (...) são menores suicidas.

Por outro lado, a polícia também é repetidamente responsabilizada pelos perigos e insegurança que vivenciam em seu cotidiano. Os moradores são muito críticos das freqüentes incursões, acusando os policiais de não cuidarem da proteção dos habitantes e agirem com a mesma falta de respeito dos traficantes que não são da "velha guarda":

$\mathrm{O}$ fato de ser comunidade de baixa renda, ou melhor, favela. Entram de forma violenta, sempre entraram, entraram com violência 
sempre... Ouço os meninos que estão desempregados, que ficam perambulando pelos becos. Eles [policiais] dizem: "estão vadiando". Dão uns tapas em todo mundo.

[Os policiais] pegaram um cara atrás da minha casa e simplesmente invadiram a minha casa. Minha casa foi arrombada. (...) porque pegaram alguém atrás. (...) devem ter pensado que todas as casas ali eram suspeitas, ali na área. Eles não respeitam não!

Afirmam que apresentar suas queixas sobre a atuação da polícia para quem não mora nas favelas é com freqüência um monólogo, pois suas críticas dificilmente obtêm repercussão na opinião pública e ainda mais remota é a possibilidade de provocar a adoção de medidas efetivas das autoridades para controlar o excesso de violência que seus agentes empregam. No máximo as reclamações se transformam em uma conversa - perigosa, diga-se de passagem, embora não tanto quanto queixar-se dos traficantes - com outros moradores, que compartilham a mesma mistura de indignação, sentimento de impotência e desamparo diante da violência policial.

(...) eles [os policiais] sabem que a maioria das pessoas (...) é leiga. Não tem de fato um esclarecimento de quais são os direitos dela, de quais os direitos da PM, da [polícia] civil... Então eles já se prevalecem disso.

(...) o mesmo policial (...) está dentro da zona sul. A diferença é que dentro da comunidade (....) que não tem como se virar contra ele..... Mas lá na zona sul (...) são pessoas que são da elite.

A possibilidade de dar publicidade a estas críticas parece depender basicamente de um agente mediador capaz de ouvir a indignação e a revolta moral e convertê-la em demanda política, acionando a linguagem dos direitos. Este lugar no passado foi ocupado pelas associações de moradores (Machado da Silva, 1967). Hoje em dia, entretanto, elas estão esvaziadas e criminalizadas, em boa parte porque a mídia e o poder público consideram que quase todas estão controladas pelos bandos de traficantes (Machado da 
Silva \& Leite, 2004). Na atualidade, o papel de mediador entre o "asfalto" (mais especificamente, as agências governamentais) e as favelas tem sido desempenhado por algumas figuras públicas, mas em especial pelas ONGs, tanto ao estabelecerem uma ponte direta com órgãos governamentais quanto por meio dos "projetos sociais" que patrocinam, autônomos ou em "parceria" com agências do governo ou organizações internacionais. Mas raramente esses intermediários "externos" atuam no campo das denúncias sobre violência policial. Neste caso, as atividades de mediação têm sido desempenhadas pelas organizações de direitos humanos e comissões legislativas de defesa destes direitos, assim possibilitando que alguns moradores se organizem e mobilizem o repertório da cidadania em busca de justiça e reparação (Freire, 2007; Farias, 2005; Leite, 2004). Mas deve-se notar que é significativa a descrença dos moradores quanto à possibilidade de averiguação dessas denúncias e de punição dos agentes envolvidos através do recurso às instituições estatais:

Imagina a gente (...) denunciando a PM que sabe onde você mora. Eles vão e te matam. Matam você e sua família toda (...).

A polícia dá um tiro na comunidade (...) agora, em quem vai pegar? Morre muita gente em comunidades e ninguém fala. Cadê os "direitos humanos"? [o morador refere-se à Secretaria Estadual de Direitos Humanos, não aos direitos em abstrato]

Na ausência de uma tradução institucional e sem repercussão pública, ou seja, quando não dispõe de operadores alternativos capazes de se fazerem ouvir no debate público em torno da justiça social, a indignação dos moradores - em casos de incursões policiais que resultam em mortes, afetando o próprio direito à vida -, tem motivado, como se sabe, alguns quebra-quebras em vias públicas. ${ }^{13}$

Ao falarem da violência e dos riscos que vivenciam em seu cotidiano, os moradores de favelas também mencionam seu isolamento e o desinteresse do restante da população da cidade pelo que acontece em suas localidades: a invisibilidade nas arenas 
políticas das violações a seus direitos humanos, a permanente insegurança em que vivem.

Quando mataram aquela menina do metrô (...) teve aquela publicidade: a Gabriela. Não discuto isso, mas quando se mata na favela assim, o Silva, o Souza (...) [referência a quatro jovens mortos por policiais na "chacina do Borel"]: "meu filho, você está fadado a morrer mesmo aqui. Você pode morrer que não tem problema. Foi condenado já".

Morreu (...) um adolescente na Cidade de Deus e cadê a mídia em cima? Não dá atenção para a família; ninguém dá assistência nem nada. (...) quando foi a garota do metrô, a governadora [Rosinha Garotinho, na época da sessão deste coletivo de confiança] foi lá, deu atenção, foi pessoalmente. Aconteceu com aqueles quatro no Borel (...) A governadora não deu atenção para nenhuma das quatro famílias.

Mas as queixas não são formuladas apenas quando o que está em tela é a violência policial. Abarcam também a insegurança produzida pela presença e atuação do crime violento nas favelas. O depoimento de uma moradora, embora longo, é ilustrativo a respeito:

Desde pequena eu ouvia que o [nome de favela em referência à facção rival aos traficantes locais] ia invadir (...) Aí, foi aquele estouro (...) Muito tiro, assim tenebrosos, eu nunca vi coisa igual (...) "É o [nome da favela da faç̧ão rival], é o [idem]!” (...) Eles quebrando vidros de carros, arrombando portas, tudo a gente ouvindo... Eles se comunicando, mandando uns se identificarem que eles não conheciam: "se identifica! se identifica!" (...) A gente ouvindo eles arrombando (...) Chegaram na minha casa (...), mandaram abrir. A gente com medo. "Se não abrir, vou jogar uma bomba!" Meu pai (...) abriu, (...) já tinham tomado a favela, eles estavam procurando algum bandido (...) alguma coisa... Só que, na nossa cabeça, era (...) para matar a gente (...). No dia seguinte, foi a pior situação. Foi o pior dia, ninguém foi trabalhar, ninguém foi estudar (...) Nessa época, foi um período de grande denúncia da televisão em relação à violência no Rio de Janeiro (...). Mas a minha maior indignação 
foi que esse episódio, que foi uma coisa assim explosiva pra gente, não teve uma repercussão que tem nesses episódios quando envolve a classe média, quando envolve o asfalto. Eu achei que ia explodir nos jornais... O nosso sofrimento (...) não apareceu no jornal. Isso para mim foi $\operatorname{assim}(\ldots)$ impactante...

Vale um comentário adicional sobre este trecho. Ao formulálo no coletivo de confiança, a moradora em questão demonstrou profunda indignação, mas também impotência e desamparo. Ninguém da favela interveio; todos se submeteram ao medo e permaneceram inativos. A moradora sequer aventou a possibilidade de reação da população local não envolvida no confronto; ela apenas mencionou que o mesmo não repercutiu na mídia (o que, implicitamente, significa dizer que não despertou o interesse das autoridades públicas, dos mediadores acima indicados ou da opinião pública em geral). Tampouco os demais participantes do "coletivo de confiança" cogitaram da possibilidade de alguma iniciativa no sentido de apresentar nas arenas políticas a demanda por segurança e, assim - como se argumentará adiante -, demonstraram que a moradora citada expressava os sentimentos do conjunto dos favelados. No relato dela, esses sentimentos estão associados, de um lado, ao reconhecimento do isolamento das favelas na cidade e de sua contrapartida, a necessidade de se submeterem à violência criminal, única forma viável de compartilhar o mesmo território com os bandos de traficantes.

Tudo isso faz retornar, agora em seus efeitos práticos, o "mito" da conivência: os moradores criticam a atuação da polícia, denunciam a omissão do poder público e a violência do Estado. Isso significa que, entre os policiais e os traficantes, eles escolhem estes últimos? Habituados em inúmeras situações a serem confrontados com esta opção pelas perguntas, diretas ou implícitas, de quem não mora nas favelas, os moradores se sentem compelidos a antecipar uma resposta, dirigindo-se sem dúvida aos pesquisadores: 
Não é que a gente goste dos traficantes, mas a gente não confia na polícia.

A comunidade, ela não vê o policial: o Ari, o José ou o Luiz. Ela vê a corporação, a aversão existe na comunidade, aversão ao policial.

Mas a polícia (...) se eles estão com uma determinada desconfiança de um certo cidadão, de uma certa pessoa, eles não vão primeiro perguntar quem é, entende? (...) A questão é essa... Então é disso aí que eu tenho medo. Então para mim tanto os marginais quanto os policiais na minha comunidade têm o mesmo, eu os vejo na mesma condição, entendeu?

Estas falas fazem parte do repertório de queixas dos moradores em relação à atuação da polícia. Muitas vezes repetidas, a própria reiteração revela com simplicidade brutal seu diagnóstico do lugar que ocupam na representação da cidade e na sociedade em que vivem: não podem confiar em uma política de segurança que não os contempla, em agentes do Estado que neles não reconhecem a dignidade indissociável da cidadania, não consideram nem protegem sua vida e seus direitos e cuja presença no território se faz sempre contra a integridade física (e, às vezes, patrimonial) dos moradores em geral. Esta "aversão" aos procedimentos típicos da atuação institucional da polícia e à conduta de seus agentes tem sido entendida como conivência com o crime violento, no quadro do pacote interpretativo constituído pelos "mitos" comentados em seção anterior. Entretanto, os trechos citados indicam que os moradores não rejeitam a polícia como instituição nem recusam (pois sequer tematizam) a necessidade de controle do crime e manutenção da ordem pública. As queixas incidem sobre sua atuação segundo um padrão de conduta indiscriminado e belicoso que excede em muito a atribuição legal do emprego de "força comedida".

Estão chegando nas comunidades e matando não sei quantos... Por quê? (...) Quer prender? Investiga. Porque eles conseguem descobrir até a cor da calcinha que alguém está usando quando querem. Hoje a polícia chega com aqueles "caveirões" [veículos blindados que a 
polícia usa durante as "operações", alegadamente para defender de ataques armados os agentes] (...), acho que aquilo é para mídia, para dizer que está trabalhando, entendeu? Se de fato quisesse trabalhar, a linha de investigação é melhor. Você pega vagabundo dormindo e não é difícil não.

Eles não estão ali para promover a proteção dos moradores e estão causando mais violência...

A mulher apanhava direto do marido (....). Um dia não agüentou, foi na cabine [da Polícia Militar, na entrada da favela]: - "meu marido (...) está bêbado, me bate, bate nas crianças." (...) [o policial:] - "eu não vou lá não para tirar ele, está quebrando tudo é a casa dele mesmo." Ela (...) foi lá no tráfico: - "acontece isso com meu marido." O cara [chefe dos traficantes] mandou falarem com ele. Deram uma coça no marido dela: - "não quero você mais no morro." Ela está tendo sossego... Então, onde você não tem um órgão competente para resolver os problemas, o tráfico controla as favelas.

Para os moradores, a ineficácia da atuação policial nas favelas, porém, não decorre estritamente de desinteresse, de preconceito em relação aos favelados, ou de medo dos traficantes. Denúncias de corrupção dos policiais são também recorrentes e fundamentam parte da desconfiança já mencionada. Os moradores apontam as práticas policiais de negociação, acordo e/ou extorsão dos traficantes como uma das principais razões do crime violento dominar suas localidades, ${ }^{14}$ desqualificando os argumentos do aparato de segurança quanto à "guerra" que está sendo travada nesses territórios, os quais, por sinal, são sustentados e corroborados pela representação construída a partir dos "mitos" que compõem o pacote interpretativo antes analisado.

A mineirada é trabalho que eles fazem, não oficial. Junta um grupo de policiais bandidos, oito, cinco, e vai assaltar "boca-de-fumo". Toma desse cara e vende para o outro cara ali na frente.

Os policiais seqüestram o traficante e daí pedem resgate. 
É uma situação cômica: você tem posto policial, tem PM aqui e os caras estão na próxima esquina, vendendo drogas ali.

Aonde eu moro, a polícia se vende. (...) Tem duas ruas (...) [os traficantes] botavam a "boca" numa rua e a polícia subia pela outra (...) recebia para subir pela outra. Quer dizer, eles faziam o trabalho deles, que é rondar a favela, mas eles subiam pela rua que não tinha "boca" e a "boca" se mantinha na outra. (....) passavam [na outra] quando iam buscar o dinheiro deles.

A polícia é malandra, a polícia é malandra. O negócio é assim: quando eles vão chegar, eles dão o primeiro tiro para o vagabundo poder correr e deixar o dinheiro lá na lata do lixo. Aí, eles vão procurar lá no lixo.

A polícia aqui, a "boca" aqui (...) [os traficantes:] - "leva uma cerveja para os caras lá embaixo". - "Aí, as cervejas que os caras mandaram para vocês". [Os policiais] sentaram aqui rindo, olhando as mulheres, rindo, entendeu? E os vagabundos aqui, que tal? É uma convivência. Aí, no outro dia, já tem aquela turma [de policiais] que não "fecha", aí vem o tiroteio e tal.

(...) o tráfico hoje infelizmente tomou conta das comunidades. Mas ele tomou conta, também, porque você tem o abandono do poder público.

Mas há ainda um outro sentido nas críticas à polícia, também recorrente nos depoimentos dos moradores.

[A polícia] não conhece ninguém, não quer saber em que casa ele vai entrar. Não quer saber de nada, porque ele não tem vínculo com ninguém. Atira para qualquer lado, não quer saber. (...) Meu filho não morreu por Deus! Eles entraram, um rapaz desceu correndo (...) O beco onde eu moro é estreitinho, tem uma saída pequenininha. Eles entraram da ponta do beco, atirando. A bala passou a um palmo da cabeça do meu filho. Meu filho tinha dois anos na época. $\mathrm{Eu}$, na hora, eu não sei nem o que eu pensei. Só escutei o barulho e gritei. Porque a polícia não quer saber em quem ele vai atirar, se ele vai atingir o bandido, se ele vai atingir trabalhador... Não quer saber, está atirando. 
Eles acham que todos nós somos traficantes, que somos coniventes.

(...) eles não entendem que a pessoa mora na favela, mas que a favela [referindo-se às representações dominantes sobre a mesma] não mora dentro dele!

Os policiais não respeitam os moradores (...) Já chegam atirando, confundem os trabalhadores com os marginais. $\mathrm{O}$ portão de entrada da minha casa eles arrombaram...

Há diferenças entre os aspectos abordados nesse conjunto de denúncias sobre o caráter indiscriminado da atuação dos policiais nas favelas e a insegurança gerada por sua conduta, a respeito dos quais os moradores não identificam recursos para se contrapor. Não obstante essa variedade, elas demonstram que o ethos policial incorporou a versão atualizada das idéias sobre as "classes perigosas" mencionada no início deste artigo. É a percepção deste fato tematizada e expressa de diferentes maneiras - que fundamenta as críticas e a desconfiança dos moradores em relação à polícia, que se estendem ao conjunto da população urbana não favelada na medida em que nesta não identificam empatia e solidariedade para combater a arbitrariedade policial, nem o reconhecimento dos perigos e insegurança que os traficantes trazem a seus locais de moradia.

A polícia andando na rua eu aceito. A polícia na comunidade eu não aceito. Por quê? Porque lá no bairro eles dão segurança (...) A polícia dentro da favela ela é um lixo e a polícia fora da favela também é um lixo?

Eles [os traficantes] agora, eles não têm respeito pela comunidade, entendeu? Lá na [nome da favela], não têm. Porque sete horas da manhã, as crianças formando para entrar [em uma escola pública] (...) eles, simplesmente porque acharam que um ia invadir o território do outro, trocaram tiro ali. Feriram o senhor que estava vendendo balas na porta da escola, feriram três crianças. Não tinha polícia. Não tinha polícia!

Eu quero justamente que o meu filho cresça, tenha um bom emprego, consiga ter uma vida diferente da que ele tem agora, consiga ter paz. 
Deitar na sua cama e levantar em paz - entre aspas, claro - mas ter segurança, um pouco mais de segurança.

(...) o medo inibe também, inibe. As pessoas se sentem traídas, eu quero contar com alguém. Mas será que eu posso contar com ele? Puxa, eu vou à delegacia, vou lá falar com o delegado, mas será que vai adiantar? (...) inclusive [os policiais] já conhecem a minha história, já conhecem a minha família e eu vou ser uma vítima [de represália]...

Para toda área do Rio de Janeiro, de asfalto, existe o "plano de segurança". Para as favelas (...) existe repressão. (...) Então quando a gente diz assim: "a polícia..." (...) Como a gente vê a polícia? (....) Ela está a serviço de quem? Ela está a nosso serviço? Ela está para garantir a nossa segurança? Como ela nos vê? Como é que o poder público é assim, esse modelo que nós temos aí, de atuação nas comunidades, isso tudo? Isso aí já vem de muitos [anos], isso aí não muda. Isso aí não muda! Isso aí não muda?

É significativo que, entre os 150 moradores de favelas ouvidos nas pesquisas, apenas uma moradora (a mesma que expressou, em depoimento antes analisado, indignação, impotência e desamparo diante da violência criminal e do isolamento das favelas na cidade) tenha relatado uma experiência positiva com a polícia, um caso em que a polícia garantiu a segurança. Atuação que mereceu não só a sua aprovação, como a levou a intervir no debate do "coletivo de confiança" discriminando esta modalidade de atuação policial na favela (uma "situação diferente") das práticas correntes e, assim, relativizando as críticas à corporação policial.

Eu queria interferir nessa coisa que está no nosso imaginário, que realmente a polícia é pior que bandido. Desde que eu era pequena, quando eu via o camburão subindo, me dava um medo... Só lembrava do conselho de meu pai: "Quando vir polícia não saia correndo! Vá devagar para casa!" A minha vontade era sair correndo e me enfiar em casa. (...) Só que vou contar uma situação diferente. (...) no nosso imaginário (...) os "meninos" são (...) os nossos guardiões. (...) [eles] falam muito isso: “(...) enquanto eu tiver aqui, não haverá invasão 
[de facção rival]." (...) Nosso temor maior sempre foi o [nome da favela em referência à facção de traficantes que a dominava]. (...) no caso da invasão, (...) os "meninos" da favela foram embora. Só que, naquela ocasião, quem garantiu a nossa segurança foi a polícia sim! (...) muitas pessoas (...) foram para a casa de algum parente e resolveram retornar caso a polícia estivesse lá. Neste momento, a polícia foi sim segurança, eu lembro bem disso, a minha família foi para a casa de minha tia porque a gente estava com medo dos bandidos voltarem. E a gente só voltou quando a polícia estabeleceu um ponto lá. Isso eu quero frisar, que é pra não deixar que a polícia é bandido.

Como se pode observar no conjunto dos relatos citados, as queixas em relação ao contexto de insegurança vivido nas favelas são dirigidas tanto à atuação policial como ao crime violento. Em relação a este, os moradores ressaltam sempre a disparidade de forças e os riscos envolvidos - que não lhes permite confrontálos abertamente - e o ônus de terem de compartilhar o mesmo território. Entretanto, se a violência policial foi tratada de uma forma relativamente unívoca pelo conjunto da população favelada, outra é a situação quando os agentes questionados são os traficantes. Devese enfatizar que as reclamações sobre a conduta dos policiais devem ser controladas e limitadas, de modo que não há uma comunicação livre, para além do fato de que, como ficou demonstrado, é muito reduzida a expectativa de que providências efetivas venham a ser tomadas a respeito. Mas essas restrições são compreendidas como fruto do isolamento e da segregação associados a um dos "mitos" que compõem a representação dominante sobre o perigo representado pelas favelas, a conivência com os traficantes. Além disso, policiais estão mais distantes dos moradores (embora muitos morem em outras favelas) de modo que sua presença parece estar menos enraizada na vida das localidades onde atuam do que o crime violento, como se verá a seguir. Isso abre um certo espaço, mesmo limitado, para criticar o comportamento dos policiais. Os traficantes, ao contrário, compartilham o mesmo território e, de uma forma ou de 
outra, acabam podendo desenvolver um controle muito mais rígido e personalizado sobre o que é veiculado. Desta forma, o medo de falar abertamente, o receio sobre os usos que os outros moradores podem dar ao que cada um diz, a possibilidade de serem definidos como alcagüetes se denunciarem publicamente os traficantes tem outras conseqüências. Como disse um morador:

(...) conivente? A partir do momento em que ele mora do meu lado e a polícia me pergunta se eu conheço, eu digo que não. (...) É uma questão de sobrevivência.

[O] secretário de segurança diz que não existe poder paralelo, que a polícia está ali para combater, vai fazer, acontecer. Mas, por debaixo do pano, vão e: - "cara, olha, a gente vai entrar". Favela-Bairro [amplo programa de urbanização (melhorias físicas) implementado pelo município em inúmeras favelas] ou alguma coisa: - "Tem que ser assim, senão não entra" (....). Então é uma loucura, como é que a gente que está lá dentro - se o próprio poder público é refém do tráfico - vai correr? Você vai para onde? Como ela falou: "você vai para a delegacia?" Não vai...

Tudo isso trunca a comunicação e leva os moradores ao silêncio, ${ }^{15}$ mas a natureza e a extensão deste é variável, assim como variáveis são as formas de lidar com as condutas violentas. ${ }^{16}$ Só quando podem falar com confiança a interlocutores conhecidos e em segurança (fora das favelas ou sob circunstâncias muito especiais), o tema afinal emerge, ainda que fragmentariamente, mas revelando que a vida cotidiana nas favelas é profundamente afetada por essa modalidade de violência. Recolhemos, assim, vários relatos de experiências de submissão, humilhação, expulsão das casas, expropriação de bens, espancamentos, assassinatos, assédio e abuso sexual cometidos por traficantes (Fridman, 2007; Leite \& Silva, 2007). Nos relatos os moradores referem-se a um poder arbitrário e quase ilimitado em relação ao qual não dispõem de recursos para se contrapor, apesar do intenso mal-estar que ele provoca, e o denunciam. 
O sujeito com um fuzil na porta da tua casa, por exemplo, você não pode falar nada. Um baseado, você não pode falar nada.

Lá ninguém pode usar vermelho (...) Eu vi: ele fez a menina tirar a blusa (...), ficou de sutiã.

O 3 se transformou em $2+1$ ou $1+2$. Lá na [nome da favela], o rapaz estava falando isso (...) porque 3 significa Terceiro Comando. Eles são do Comando Vermelho agora. Eram do Terceiro. É a repressão, é o regime talibã de que falei. É horrível!

Mas, além disso, frisam que o registro de suas queixas por segurança é outro. Como demandar respeito a seus direitos, à sua integridade pessoal, de "bandidos"?

... o tráfico (...) é violento. Mas por que a gente sempre fala da PM? Porque o traficante a gente sabe: é o bandido, está à margem da lei. A gente pode esperar o quê dele? Só isso mesmo.

Deve-se ressaltar que, para os moradores de favelas, o silêncio e a submissão diante da violência do tráfico constituem as respostas possíveis à opressão dos traficantes, diante do que vivenciam como isolamento e desamparo. Neste cálculo, expressam um certo reconhecimento da operação da "geometria variável" em relação às favelas e seus habitantes, como indica a seqüência abaixo, um diálogo que se processou em um dos "coletivos de confiança":

- O tráfico, gente, é realmente o poder paralelo, eles são o poder, então eles têm as regras deles. A gente não é cidadão para o tráfico, a gente é cidadão para o governo, para a sociedade. Para o tráfico, a gente é subordinado.

- Entre aspas, porque a gente não é cidadão para nenhum dos dois. Porque ontem meu irmão levou uma cacetada na cabeça, da polícia.

Sem dúvida, silêncio e obediência são respostas adequadas diante do risco de vida e da inexistência (ou extrema precariedade) 
de soluções institucionais - mas, ao mesmo tempo, renovam as dificuldades enfrentadas. Aqui, é interessante chamar a atenção para o fato de que o silêncio (e, mais geralmente, as distintas formas de omissão, as quais não devem ser entendidas como passividade ou desinteresse) constitui um dispositivo de defesa. ${ }^{17}$ Entretanto, traduzido na chave de leitura da "conivência", estimula a violência policial indiscriminada; aprofunda o isolamento dos moradores, quebrando a confiança associada à sociabilidade local; ${ }^{18}$ reforça os estereótipos da população não-moradora; e fornece justificativas para a criminalização de seus protestos (eventuais quebra-quebras, por exemplo) e das ações coletivas mais orgânicas, dificultando e mesmo impedindo a participação dos favelados nas arenas políticas como atores moralmente qualificados. Tudo isso, evidentemente, reforça o que poderia ser chamado de uma "lei do silêncio" branca, implícita, imposta pelos traficantes de drogas nesses locais. ${ }^{19}$ Assim, fecha-se um círculo de ferro, na medida em que esses obstáculos contribuem decisivamente para que silêncio e omissão reapareçam como dispositivos de defesa da população local, formas de ajustamento dos moradores aos dilemas postos pela atual configuração da violência policial e criminal, com vistas a prosseguir em suas atividades regulares.

Vale aqui um comentário sobre as diferenças entre os agentes da violência nas favelas. Como foi sugerido, os moradores não dispõem das mesmas alternativas quando se trata da violência policial. No caso desta, silêncio e omissão não têm utilidade como recursos defensivos. Nem são impostos explicita ou implicitamente pelos policiais, posto que, salvo raras exceções, eles sabem que estão lidando com uma população segregada e estigmatizada, de modo que não se esforçam por garantir a clandestinidade das ilicitudes que possam cometer. Além do mais, só muito raramente eles têm algum interesse na vida local: constituem um poder que interfere de fora e sobre o qual a população moradora não tem qualquer ingerência, 
através das famosas "operações", das várias formas de contato com os traficantes e/ou da simples omissão. Neste sentido, para os moradores comuns a violência policial é inapelável, incontrolável e imprevisível. É evidente que a relação polícia-morador é territorializada (como indicado em alguns trechos já citados dos relatos, a atitude dos policiais nas favelas não é a mesma que eles adotam fora delas). No entanto, do ponto de vista dos moradores comuns, a territorialização é espasmódica e intermitente - e esse distanciamento torna incontroláveis as condutas dos policiais. Em outras palavras, a presença desses atores nas favelas é um elemento do cotidiano; mas quando, onde e como sua atuação interferirá na vida dos moradores comuns é imprevisível.

É mais fácil você conseguir o respeito de um bandido do que respeito da polícia.

Porque a polícia pra gente, pelo menos para mim, ainda é pior que o traficante. (...) eu acho que com o traficante ainda eu posso, como é que é?, argumentar, negociar...

Pergunta do pesquisador: - Ele falou "não dá para generalizar". O que pode generalizar e o que não pode? (...) Ela disse: "a atuação da polícia na favela você pode generalizar”. É verdade?

Resposta: - Pode sim, em toda comunidade violenta é o mesmo: a polícia cada vez que entra no morro é para matar.

Há diferenças significativas no que diz respeito à atuação dos traficantes: para estes o domínio territorial é de grande importância logística, de modo que sua dominação precisa ser exercida de modo muito mais estrito, permanente e regular. Se, por um lado, isto implica maior opressão e controle das atividades dos moradores comuns (a "lei do silêncio", por exemplo), por outro também significa uma certa aproximação que as diferenças nas disposições subjetivas e as barreiras morais não podem evitar. ${ }^{20}$ Neste sentido, a proximidade forçada abre certo espaço, ainda que limitado, para algumas tentativas de controle ou redução dos efeitos da violência 
dos traficantes (quase sempre no quadro de interações face a face). Com isso, surge a possibilidade de diminuir a imprevisibilidade da atuação dos traficantes por intermédio de um cálculo dos riscos derivados da presença forçada dos traficantes no mesmo território em que vivem os moradores comuns. ${ }^{21} \mathrm{~A}$ complexidade desses contatos $^{22}$ é enorme; sem entrar nos detalhes, seu sentido geral será comentado oportunamente. Aqui, basta acrescentar que certos tipos sociais, por seu estatuto simbólico - mães e líderes religiosos (em particular evangélicos ${ }^{23}$ ) por exemplo -, dispõem de melhores condições de manipular as relações com os traficantes, muitas vezes utilizando essas "imunidades", mesmo precárias, como recurso de contra-poder. ${ }^{24} \mathrm{Se}$ bem-sucedido, esse recurso pode bloquear pontualmente as explosões de violência características de grande parte das condutas dos traficantes, introduzindo não propriamente uma dimensão de confiança nesses contatos, mas, pelo menos, alguma previsibilidade sobre o curso das ações.

\section{Conclusão: sobre riscos e rotinas nas favelas}

Para apresentar as conclusões do artigo, é necessário sintetizar alguns pontos analisados nos relatos dos moradores, buscando ao mesmo tempo compreender o sentido subjacente às suas falas. Viuse que a descrição das formas de atuação da polícia nas favelas é sempre acompanhada de críticas acerbas. Estas, entretanto, não se dirigem propriamente à corporação (ninguém é contra a repressão policial), nem tampouco aos métodos violentos em si mesmos. As críticas são antes ao caráter indiscriminado da ação que não distingue entre "gente de bem" e "marginais". Em outras palavras, o que os moradores criticam é menos a violência policial em si e mais a falta de seletividade de seu objeto.

Deve-se notar que parte das críticas à atuação da polícia denuncia a corrupção e a inação policial nos postos situados nas 
localidades, em geral na periferia delas, sugerindo que a aceitação de métodos violentos tem como limite sua funcionalidade como "garantia externa" da ordem social local. Pode-se acrescentar, ainda, que a crítica não se organiza a partir da denúncia das ilegalidades cometidas pelos policiais (exceto em alguns casos de mortes por eles provocadas, como argumentado antes), mas antes como reação aos desajustamentos que suas práticas introduzem no fluxo das interações rotineiras nos territórios favelados. A causa das interrupções nele produzidas pela violência policial algumas vezes é atribuída aos estereótipos e preconceitos contra os favelados (há uma clara compreensão de que os policiais não agem da mesma forma na "favela" e no "asfalto"). Mas a menção ao preconceito constitui uma outra forma de crítica. Neste caso, reconhecem que a polícia não é ator, mas instrumento, dispositivo, da construção do "problema da violência" e de medidas para sua solução articuladas a partir da "geometria variável".

Uma conclusão geral sobre as críticas à violência policial pode ser resumida da seguinte maneira. Elas denunciam a violência, mas estão referidas a outro problema: a quebra das rotinas. É esta questão não tematizada que organiza todo o discurso crítico e "ajusta" (justesse) o ponto de vista das camadas sociais mais abastadas (segregador, estereotipado e preconceituoso) e o dos moradores de favela (bem como dos demais territórios da pobreza). Estas duas categorias - favelados e moradores do "asfalto" - do imaginário sobre o Rio de Janeiro, centrais na configuração da estratificação social da cidade e seus conflitos, acabam se encontrando naquilo que não dizem: a intensa preocupação com o prosseguimento das rotinas cotidianas, vividas como sistematicamente ameaçadas pela violência. No caso dos moradores de favelas, o que está em questão não é a regulação estatal/legal, a democracia (embora este tópico apareça implícito nas reclamações sobre as diferenças de tratamento no "asfalto" e na "favela"), nem a restrição da violência. O problema 
criticado é, antes, o desrespeito às diferenças e hierarquias internas que constituem a versão local da ordem social.

A descrição das formas de atuação dos criminosos também vem sempre acompanhada de crítica, mas sob outro quadro de referência, que incorpora uma periodização ausente no entendimento da violência policial. O que revela que, a despeito da clara percepção dos moradores sobre a mudança do estatuto da violência criminal nas favelas, o impacto desta sobre seu cotidiano/suas rotinas era tido como previsível e manipulável. Em outras palavras, nos relatos atuais, os moradores afirmam que "antigamente" a atividade criminal não afetava o fluxo regular da vida local por estar "ajustada" a ele. Além disso, podia até mesmo contribuir para a regulação das rotinas, na medida em que este ajustamento convertia os criminosos em uma espécie de pequena autoridade local. Por outro lado, a atividade criminal sendo intersticial e menos ostensiva, a atuação da polícia também o era. Assim, os moradores parecem considerar que o segredo, a clandestinidade e a invisibilidade pública da atividade criminal, provocando certo desinteresse (da polícia, da população "de fora" e dos próprios moradores) por ela, eram característicos desse passado idealizado. Ao contrário, "hoje" os criminosos/ traficantes se orientam segundo um padrão de sociabilidade próprio que é incompatível com as regras de convivência dos moradores comuns. As críticas às humilhações, à falta de "respeito"- elemento central do repertório crítico dos moradores de favelas - traduzem sua percepção acerca da unilateralidade da submissão imposta pelos agentes da "sociabilidade violenta" (cfr. nota 12) que praticamente cancelam o reconhecimento de sua humanidade.

Frente a esta forma de vida, os moradores comuns desenvolvem um esforço de "limpeza simbólica" que é de dupla natureza. De um lado, procuram afastar-se do mundo do crime, reivindicando não serem identificados com os criminosos, enfatizando sua natureza ordeira e pacífica e os padrões de moralidade burguesa que seguem. 
Deve-se ressaltar, nesta operação, a ressignificação do sentido do termo "vagabundo", tal como incorporado na linguagem corrente pelos próprios moradores de favelas. No passado foi uma categoria externa de criminalização aplicada ao conjunto dos favelados enquanto membros das "classes perigosas", articulada a partir das referências do mundo do trabalho (Valladares, 2005; Zaluar, 1985). Hoje, tornou-se uma categoria "nativa" que se refere ao crime e à violência, estabelecendo diferenças internas e demarcando fronteiras entre as pessoas/ "cidadãos de bem" e os "vagabundos" residentes em favelas.

De outro lado, como muitas vezes os traficantes são parentes, vizinhos ou conhecidos próximos, os moradores desenvolvem um esforço sempre individualizado e pontual para "re-humanizar" ou "re-moralizar" a pessoa em questão, do tipo "ele está nesta vida, mas..." e acrescentando alguma característica moralmente positiva. Ou seja, não se trata de justificar as práticas criminais. Os moradores apenas sugerem que, mesmo adotando uma forma de vida reprovável, a pessoa teria características que a tornam "gente como a gente" e não um monstro moral.

Paralelamente ao reconhecimento da radical incompatibilidade entre formas de vida contíguas compartilhando o mesmo território, são muito intensas as manifestações de reprovação, desconforto e medo relacionadas aos constantes confrontos armados entre bandos de criminosos. Uma conclusão geral sobre as críticas dirigidas à violência criminal caminha na mesma direção das críticas à atuação dos policiais. Não é propriamente nem o crime nem a violência que organizam o discurso crítico, mas sim, como se viu nos relatos analisados, a interferência desta forma de vida sobre o fluxo rotineiro da vida nos territórios das favelas.

Tudo isto sugere que a "presença ausente" (não reconhecida, logo não tematizada) no discurso sobre a violência policial e criminal 
dos moradores de favela é a preocupação com a continuidade das rotinas cotidianas, ou melhor, o caráter imprevisível das freqüentes interrupções que elas sofrem. Uma utilização livre do que Giddens (1997, 1991, 1989) designa de "segurança ontológica" permite pensar que também esta depende de "garantias externas" (que, para este autor, estariam vinculadas aos "sistemas peritos"). É necessário reconhecer, entretanto, que não se pode presumir a confiança dos moradores de favelas nas instituições estatais encarregadas da proteção aos cidadãos. Operando no quadro da "cidadania de geometria variável", estas, com freqüência, trazem incerteza e insegurança à vida dos segmentos subalternos da população, uma vez que, em sua extensão e qualidade, os bens de cidadania e os serviços públicos diferenciam-se social e espacialmente e a lei escrita não se aplica universalmente a todos os casos e segmentos sociais. Vale observar que a noção de "sistema perito" de Giddens está associada à burocratização do conhecimento sob a forma de organizações incrustradas na vida cotidiana e supõe um universalismo que não existe no caso de alguns sistemas no Brasil, cujas regras de funcionamento, embora burocratizadas, são ao mesmo tempo contingentes e contexto-dependentes. Dito de outro modo, no caso em análise, as "garantias externas" não provêm do conjunto de aparelhos ou campos (que tendem ao monopólio da violência, simbólica ou material) de controle social, depositários da capacidade de impor regras generalizadas de conduta.

O material coletado sugere que é a experiência prática e imediata de uma ordem rotineira estável (aquilo que permite "continuar", como diz Giddens) que fornece tais garantias, orientando os moradores sobre como ajustar suas condutas às situações de violência, perigo e insegurança. Isto leva a crer que o funcionamento institucional, com seus respectivos conflitos, é fortemente influenciado pelos modos concretos de lidar com a experiência cotidiana da densidade do mundo necessária à "segurança ontológica". Em outras palavras, tais garantias são representadas 
por rotinas suficientemente estabilizadas, capazes de incorporar a possibilidade de "prosseguir" em situações extraordinárias, que passam a ser cognitiva e moralmente manipuladas como "riscos" e não como bloqueio das condições "objetivas" (isto é, da organização das rotinas) para "continuar". Este bloqueio é vivido como um perigo cada vez mais "inadministrável", proveniente do próprio funcionamento institucional, no caso da violência policial, ou das ameaças representadas por uma forma de vida contígua mas incompatível com a dos moradores comuns, no caso da violência criminal.

Por fim, cabe ressaltar que a ansiedade gerada por esta ameaça à segurança ontológica expressa-se sob a forma de um medo social difuso, que atinge toda a população da cidade, inclusive os moradores de favela, e que acaba por produzir demandas de uma recomposição das rotinas pela força, fechando assim um círculo de ferro que reproduz indefinidamente a violência como elemento estruturador fundamental, sempre presente e sempre temido, nas favelas e em toda a cidade.

\section{Notas}

1 "Human rights, poverty and violence in Rio de Janeiro, Brasil: slum dwellers searching for recognition and access to justice", Small Grants Programme for Research on Poverty and Human Right/UNESCO, 2005/2006, coordenada por Machado da Silva e Márcia Leite, e "Rompendo o cerceamento da palavra: a voz dos favelados em busca de reconhecimento", Faperj, 2005/2007, coordenada por Machado da Silva. A equipe de pesquisadores, comum às duas investigações, foi constituída por Luiz Antonio Machado da Silva (Iuperj-Ucam e IFCSUFRJ), Márcia Pereira Leite (UERJ), Luís Carlos Fridman (UFF), Jussara Freire (Iuperj e Ibemec), Wânia Mesquita (Uenf), Lia Rocha (Iuperj), Juliana Farias (UERJ) e Itamar Silva (Ibase). Os resultados apresentados neste artigo são fruto de um processo de elaboração cole- 
tiva, mas, certamente, a responsabilidade pelo seu conteúdo é dos autores.

2 Os grupos foram organizados por local de moradia, privilegiando segmentos de moradores de favelas que, conforme constatado em diversas investigações, vêm sendo atingidos com especial intensidade pela atuação do crime violento e/ou têm construído alternativas diversas para resistir. Neste caso, foram selecionados moradores de favelas com inserção em ações coletivas (dirigentes de organizações de base e articuladores de projetos sociais, além de participantes em ambos), mulheres/mães, jovens de 15 a 24 anos e moradores com diferentes filiações religiosas. Não se pretendeu que os grupos fossem estatisticamente representativos da variedade de orientações individuais; apenas buscou-se cobrir os segmentos sociais mais diretamente ligados à temática pesquisada. Além da confiança prévia, a escolha de seus componentes enfatizou o interesse na investigação por parte dos escolhidos, sua atitude colaborativa e fluência verbal. Evidentemente, estes são critérios arbitrários que, entretanto, introduziram um bias favorável à coleta do tipo de informação visada. Os 150 moradores ouvidos distribuíram-se como segue: 43 jovens, de 15 a 24 anos de idade, e 107 adultos de diferentes idades; 60 homens e 90 mulheres. $\mathrm{O}$ número de mulheres traduz a maior participação deste segmento nas redes políticas, religiosas e comunitárias nas favelas.

3 Grupos paramilitares compostos em geral por policiais da ativa ou expoliciais, bombeiros etc., nem sempre moradores de favelas, e muito bem armados.

$4 \mathrm{Na}$ análise das narrativas e debates assim recolhidos, os pesquisadores dedicaram-se à tipificação das tendências dos quadros cognitivos, morais, etc. que orientam as ações dos participantes dos "coletivos de confiança", sempre considerando o grupo, e não seus componentes individuais, como unidade de análise (cfr. Krueger, 1988). É desta forma que devem ser lidas as citações de trechos dos relatos neste artigo.

5 Sobre a noção de "violência urbana" como representação social, cfr. Machado da Silva (2007; 1995; 1993). Trata-se de uma generalização muito ampla, que abrange grande leque de atitudes, condutas e 
situações variavelmente criminalizadas (cfr. a noção de "processo de incriminação" em Misse, 1999), mas cujo núcleo são as ameaças à integridade física e patrimonial. Pelos relatos dos moradores, nas favelas esta noção é mais restrita do que no conjunto da população da cidade, uma vez que as ameaças são sempre associadas ao tráfico de drogas e à reação da polícia.

6 Para uma boa apresentação deste conceito, cfr. Fuks (2001). Para uma discussão de seu lugar no corpus conhecido como "construcionismo", cfr. por exemplo Holstein e Miller (1993), Gamson (1992), Hilgartner e Bosk (1988) e Gusfeld (1981).

7 Jovens favelados são alvo do tráfico e da polícia, constituindo as principais vítimas e algozes do crime violento, como demonstraram Soares et al. (1996). Pesquisa da ONG Viva Rio revelou que, em 2001, $65 \%$ das mortes de rapazes de 15 a 19 anos no município do Rio de Janeiro foram provocadas por armas de fogo. As taxas de morte por arma de fogo distribuem-se da seguinte maneira segundo a faixa etária: de 15 a 19 anos $=175,7 / 100.000$ habitantes (a taxa das mulheres é 7,2 ); de 20 a 29 anos $=214,5$ (mulheres 8,1). O risco de um jovem ser assassinado é quatro vezes maior na faixa dos 15 aos 29 anos do que na média do conjunto dos moradores (Viva Rio, 2002). Cfr. também Dowdney (2003) e Peralva (2000).

8 Um dos autores deste trabalho tem sugerido que, ao invés de um confronto de poderes, há contiguidade territorial de duas ordens sociais sustentadas por modos de coordenação das ações radicalmente distintos. Para elaborar este ponto, propõe a noção de "sociabilidade violenta" (Machado da Silva, 2007; 2006; 2004a, 2004b; 1995; 1994), a partir da qual é sugerido que os bandos de traficantes vêm constituindo uma forma de vida autônoma, em cujo núcleo estão disposições e condutas que reduzem a intersubjetividade a quase nada e para as quais a força física (com os objetos que a ampliam) é a única referência. (De certa maneira, a noção se aproxima do conceito de "regime de violência" discutido por Boltanski (2000, esp. p. 105-118), também mencionado em Boltanski e Thévenot (1991), embora não possa ser identificada com ele, na medida em que remete a uma forma de vida autônoma que não é 
compatível com a teoria desenvolvida por estes autores). Assim, a força, de meio de obtenção de interesses, transforma-se em um princípio de coordenação. Portanto, é característica da "sociabilidade violenta" uma racionalidade estritamente instrumental que, praticamente, suspende a alteridade e a produção de sentido intersubjetivo, mas não impede a coordenação das ações nem o prolongamento das relações ao longo do tempo. É claro que coordenação instrumental pura, sem produção de sentido, não existe. Logo, a "sociabilidade violenta" deve ser entendida como uma construção típico-ideal, considerada útil para compreender uma forma de vida historicamente constituída que se afasta menos desse construto do que outras.

9 "Desta perspectiva, a tarefa dos antropólogos é observar as instâncias do Estado tal como existem no nível local e, a partir daí, analisar essas manifestações locais da burocracia e da lei como interpretações ou apropriações, culturalmente informadas, das práticas e formas que constituem o Estado liberal moderno" (Das \& Poole, 2004, p. 5-6, tradução dos autores).

$10 \mathrm{O}$ artigo lida apenas com os relatos coletados durante as sessões dos "coletivos de confiança", até porque há congruência com o restante do material empírico. Também é necessário acrescentar que aqui são incorporados apenas os relatos a respeito da violência policial e dos traficantes de drogas. Razões de tempo e espaço levaram à decisão de não incorporar a análise das referências (algumas favoráveis, outras contrárias) à submissão dos moradores pelas milícias, a despeito da disponibilidade de bastante informação sobre uma favela submetida a uma milícia (cfr. Mesquita, 2007), cujo principal líder foi eleito vereador (o que torna o caso pesquisado estratégico para compreender a dinâmica dessa configuração na atualidade). Finalmente, vale ressaltar que: a) o que hoje é chamado de milícia não é um fenômeno novo, embora esteja significativamente transformado em relação às práticas e ao sentido originais; b) o desenho de pesquisa não foi pensado para incluir a possibilidade de analisar os confrontos tráfico-milícia que vêm se multiplicando no Rio de Janeiro.

11 Evidentemente, há diferenças entre grupos específicos de moradores a respeito. Por exemplo, nos "coletivos de confiança” com dirigentes de 
organizações de base em favelas, os modos destes abordarem e/ou de evitarem o tópico da violência policial e criminal estavam fortemente vinculados às estratégias de apresentação de si (e às justificações correspondentes) para seus pares, para os pesquisadores e, através destes, "para fora" da favela, no contexto de criminalização e esvaziamento dessas organizações analisado adiante (Freire, 2007).

12 Tem sido equivocadamente atribuído aos moradores o uso genérico da categoria "meninos" para designar os traficantes. Nos relatos em análise, ao contrário, o uso desta expressão por moradores comuns via de regra restringia-se aos traficantes "crias do morro", i.é, que cresceram na localidade, foram vizinhos, amigos, são parentes. Como recurso discursivo, evocava relações construídas no passado - mesmo se rompidas no presente -, a fim de promover uma certa "remoralização" que permitisse reincorporá-los como membros da "comunidade" (vejase os depoimentos já apresentados) e diferenciá-los dos "menores suicidas"/“juventude Bin Laden" - duas categorias reservadas aos traficantes "de fora" e referidas às suas explosões de violência na localidade. Deve-se considerar que, de um lado, esta "remoralização" algumas vezes traduzia uma tentativa de compatibilizar dois registros de "limpeza simbólica" "para fora" das favelas: um, envolvendo a diferenciação geral entre moradores e criminosos; outro, através de uma distinção mais específica, entre traficantes "crias" versus "de fora". De outro lado, deve-se considerar também o efeito prático pretendido "para dentro" das favelas: a tentativa de interpelar os traficantes a partir deste quadro de referência e a expectativa - nem sempre correspondida - de que eles demonstrassem algum "respeito" pelos moradores, restringindo suas demonstrações de força. Sobre o tema cfr. Leite (2007a).

13 Sobre o tema da indignação e da revolta em situações percebidas como de "injustiça", cfr. Leite (2004) e Moore Jr. (1987). Note-se que o recurso aos mediadores e os quebra-quebras são apenas formas coletivas de reação (menos comuns, poder-se-ia acrescentar) à violência nas favelas. Soluções privadas, ao nível de decisões familiares, como mudar-se para outras favelas aonde não haja "matadores", retornar ao estado de origem se migrante, etc., também são recorrentes. 
14 Cfr. Misse $(1999,1997)$ para as relações entre violência, "mercadorias políticas" e "economia da corrupção".

15 Como disse uma moradora: “a gente só está conversando [nos coletivos de confiança] porque [sabe que] ninguém vai ser identificado”. Apesar disso, outro morador cortou repentinamente o relato das condutas violentas de membros do bando de traficantes que atua na favela onde mora para manifestar um temor generalizado e difuso: "os traficantes sabem tudo que eu faço". Este receio indeterminado talvez se relacione com o que outros moradores identificaram como "neurose" ou "nóia" [paranóia], que parece traduzir em linguagem psi, ao mesmo tempo, uma reação individual e defensiva à extensão da submissão imposta pelos traficantes e um certo reconhecimento de que ela pode ser um tanto exagerada. Cfr. Farias (2007) e Mattos (2006). Notar que esta reação defensiva se manifestou inclusive entre moradores da favela em que não havia, no momento do trabalho de campo, "bocas-de-fumo" (cfr. Rocha, 2007).

16 Certamente, os moradores conversam e comunicam suas queixas. As referências desaprovadoras a muitos aspectos das condutas dos traficantes são constantes. No entanto, há sempre extrema cautela em só fazê-las privadamente, como verdadeiras confidências, tomando os maiores cuidados para garantir que apenas pessoas de reconhecida confiança estejam presentes e que o ambiente seja favorável. Desse modo, fatos, situações e pessoas são mencionados, mas o segredo é requerido e sua inevitável circulação como "fofoca" é temida. (Fofocas podem fazer vítimas, dependendo de quem as usa e como são usadas; nas circunstâncias da vida nas favelas isso pode significar a morte.) Neste sentido, as reclamações, em particular as que se referem à violência dos traficantes - pois, como se verá, a opressão da polícia é mais distante - têm limitada possibilidade de se estruturar como uma crítica orgânica e compartilhada, capaz de articular uma ação coletiva consistente nas arenas políticas. Este é mais um fator de deslegitimação e enfraquecimento das organizações de base e das poucas reivindicações que elas conseguem conduzir.

17 Conforme indicado, por exemplo, nas notas 15 e 16. 
18 Os autores consideram a hipótese de que esteja em curso, em certas favelas cariocas, uma erosão do "sentido de lugar", como sugere Wacquant (2001b) em sua análise de territórios estigmatizados e isolados em diferentes contextos nacionais.

19 Inúmeros trabalhos abordam, sob diferentes ângulos, este ponto. Cfr., por exemplo: Farias (2007); Fridman (2007); Leite (2007a; b); 2005); Rocha (2007); Machado da Silva, Leite e Fridman (2005); Machado da Silva e Rivero (2005); Machado da Silva (2004a; b); Machado da Silva e Leite (2004); Zaluar (2004; 1995; 1985); e os artigos reunidos em Zaluar e Alvito (1998).

20 Esta contigüidade territorial entre traficantes e moradores - comuns nas favelas - tem requerido, da parte destes últimos, um diuturno trabalho de "limpeza simbólica": as fronteiras morais que os separam - ou seja, a desaprovação da forma de vida dos traficantes - precisam ser recorrentemente reafirmadas. Esta necessidade é mais forte nas relações com não moradores e com organizações "de fora", mas também está presente entre os próprios moradores. Os autores fazem menção a essa questão, porém não há espaço neste artigo para um tratamento sistemático. De qualquer forma, há evidência de que é um problema angustiante, especialmente para os que têm parentes e/ou amigos envolvidos nas ações violentas relacionadas ao comércio de drogas.

21 Para Giddens (1991, p. 40), "perigo e risco estão intimamente relacionados, mas não são a mesma coisa. A diferença não reside em se um indivíduo pesa ou não conscientemente as alternativas ao contemplar ou assumir uma linha de ação específica. O que o risco pressupõe é precisamente o perigo (não necessariamente a consciência do perigo). Uma pessoa que arrisca algo corteja o perigo, onde o perigo é compreendido como uma ameaça aos resultados desejados. Qualquer um que assuma um "risco calculado" está consciente da ameaça ou ameaças que uma linha de ação específica pode pôr em jogo". Cfr. também a discussão sobre "o retorno da incerteza" em Beck (1997, p. 19-24).

22 Embora não seja o caso de discutir este problema, talvez o termo "contato" seja mais adequado do que "interação" ou "relação", na 
medida em que traficantes e moradores comuns têm disposições para a ação radicalmente distintas e não compartilham as mesmas formas de vida.

23 A elaboração de uma identidade religiosa evangélica, que unifique crenças, valores e práticas pertinentes a esta filiação, tornou-se nos últimos anos uma das principais modalidades de "limpeza simbólica" nas favelas, permitindo que evangélicos estabeleçam contatos com traficantes - inclusive na tentativa de evangelizá-los - sem se contaminar moralmente. Cfr. Leite e Machado da Silva (2007); Zaluar (2004); Birman (2003); Birman e Leite (2002); Mafra (1998).

24 Em situações de risco, o significado simbólico de certos papéis sociais usualmente é acionado na tentativa de obter "imunidade". No caso dos evangélicos, por meio de uma conduta compatível com a esperada da filiação religiosa, do uso da Bíblia, etc. No caso das mães, através do recurso discursivo aos "laços primordiais" - "as igualdades de sangue, fala, costumes" - experimentados como "vínculos inefáveis, vigorosos e obrigatórios em si mesmos" (Geertz, 1978, p. 261). Para o tema consultar Leite (2007a; b) e Leite e Machado da Silva (2007).

Violence, crime and police: what do people who live in slums say when they talk about these subjects?

Abstract: The article is based on two qualitative research projects held in Rio's favelas. The empirical material is drawn from one of its activities - conducting and recording approximately 50 hours of a process that has been denominated as "trust collectives". This expression intends to stress the way participants of 15 focal groups (involving 150 residents of more than 40 favelas) were recruited - acquaintance and trust built through previous relationships with at least one of the researchers. This criterion was planned as a way of minimizing the expected effects of the "law of silence" imposed by agents of violence in these localities. The text analyzes enunciations collected during these debates, which were clearly concentrated on the different ways in which criminal gangs and police forces make their presence and behavior felt within Rio de Janeiro's favelas. 
The authors sustain that, less than questioning criminal and police violence as a whole, favela residents are intensely worried about some of its manifestations which prevent them from carrying out their daily activities. Without being directly taken up as a theme for dialogue, this is the horizon that calls out their attention and that organizes all their critical comments to "people outside", as well as their attitudes and behavior towards their fellow favela inhabitants. The authors go further by arguing that, in their descriptions and denouncements, residents do not homogenize the agents they consider responsible for destabilizing their routines. On the one hand, there are institutional police practices (the famous "operations" - recurrent raids on favelas in order to fight drug dealers) and the arbitrariness of agents' regular behavior, both of which are felt to be almost completely unpredictable. On the other hand, when dealing with the violent practices of drug dealers, with whom residents are obliged to share their territory, there were many accounts of attempts (successful or not) of reducing the unpredictable quality in the flow of daily life. This occurs by adjusting behavior to a calculation - unworkable and/or ineffective in the case of police action - of the risks involved in such a situation of forcibly sharing the same space. This calculation, making a small part of local violence easier to "administrate", permits re-absorbing it as an "extraordinary" part of "ordinary" routines.

Keywords: violence, crime, police, routine, risk, sociability.

\section{Referências}

ANDERSON, Benedict. Imagined communities: reflections on the Origin and Spread of Nationalism. London: Verso, 1983.

ASAD, Talal. Where are the margins of the state? In: DAS, Veena; POOLE, Deborah (Ed.). Anthropology in the margins of the state. New Delhi: Oxford University Press, 2004.

BECK, Ulrich. A invenção da política: rumo a uma teoria da modernização reflexiva. In: GIDDENS, A.; BECK, U.; LASH, S. Modernização reflexiva: política, tradição e estética na ordem social moderna. São Paulo, Ed.UNESP, 1997. 
BIRMAN, Patrícia. Imagens religiosas e projetos para o futuro. In: BIRMAN, P. (Org.). Religião e espaço público. Brasília: Attar Editorial/CNPq-Pronex, 2003.

BIRMAN, Patrícia; LEITE, Márcia Pereira. Qu'est devenu l'ancien plus grand pays catholique du monde?. Problèmes d' Amérique Latine, n. 46/47, 2002.

BOLTANSKI, Luc. El amor y la justicia como competencias: três ensayos de teoría de la acción. Buenos Aires: Amorrortu, 2000.

BOLTANSKI, Luc; THEVENOT, Laurent. De la justification. Les économies de grandeur. Paris: Gallimard, 1991.

BRODEUR, Jean-Paul. Por uma sociologia da força pública: considerações sobre a força policial e militar. Caderno CRH, v. 17, n. 42, 2004.

CECCHETTO, Fátima. Violência e estilos de masculinidade. Rio de Janeiro: FGV, 2004.

CHEVALIER, Louis. Classes labourieuses et classes dangereuses. Paris: Hachette (Pluriel), 1984.

DAS, Veena; POOLE, Deborah (Ed.). Anthropology in the margins of the state. New Delhi: Oxford University Press, 2004.

DOWDNEY, Luke Crianças do tráfico: um estudo de caso de crianças em violência armada organizada no Rio de Janeiro. Rio de Janeiro: 7 Letras, 2003.

FARIAS, Juliana. Da asfixia: reflexões sobre a atuação do tráfico de drogas nas favelas cariocas. In: ROMPENDO o cerceamento da palavra: a voz dos favelados em busca de reconhecimento. Relatório pesquisa Faperj. 2007. [não publicado].

Movimento 'Posso me identificar?: de objetos da violência a sujeitos da política. Monografia (Bacharelado em Ciências Sociais) - DCS/UERJ, 2005.

FREIRE, Jussara. Agir e elevar a voz em um regime de ação violento: indignação, denúncia e ordem social no Rio de Janeiro. In: ROM- 
PENDO o cerceamento da palavra: a voz dos favelados em busca de reconhecimento. Relatório pesquisa Faperj. 2007. [não publicado].

FRIDMAN, Luís Carlos. Morte e vida favelada. In: ROMPENDO o cerceamento da palavra: a voz dos favelados em busca de reconhecimento. Relatório pesquisa Faperj, 2007. [não publicado].

FUKS, Mário. Conflitos ambientais no Rio de Janeiro: ação de debate nas arenas públicas. Rio de Janeiro: UFRJ, 2001.

GAMSON, William. Talking politics. Cambridge: Cambridge University Press, 1992.

GEERTZ, Clifford. A interpretação das culturas. Rio de Janeiro: LTC, 1978.

GIDDENS, Anthony. A vida em uma sociedade pós-tradicional. In: GIDDENS, A.; BECK, U.; LASH, S. Modernização reflexiva: política, tradição e estética na ordem social moderna. São Paulo UNESP, 1997.

. As conseqüências da modernidade. 3. ed. São Paulo: UNESP, 1991.

. A constituição da sociedade. Rio de Janeiro: Zahar, 1989.

GRAMSCI, Antonio. Maquiavel, a politica e a história. Rio de Janeiro: Civilização Brasileira, 1976.

GUIMARÃES, Alberto Passos. As classes perigosas: banditismo rural e urbano. Rio de Janeiro: Graal, 1981.

GUSFIELD, Joseph. The culture of public problems: drinking-driving and the symbolic order. Chicago: The University of Chicago Press, 1981.

HILGARTNER, Stephen; BOSK, Charles. The rise and fall of social problems: a public arenas model. American Journal of Sociology, v. 94, n. 1, 1988.

HOLSTEIN, J.; MILLER, G. Reconsidering social constructionism: debates in social problems theory. Nova York: Aldine de Gruyter, 1993. 
KRUEGER, Richard. Focus group: a pratical Guide for Applied Research Sage. California: Newberry Park, 1988.

LAUTIER, Bruno. Os amores tumultuados entre o Estado e a economia informal. Contemporaneidade e Educação, v. 2, n.1, 1997.

LEITE, Márcia Pereira. Cidadania, sociabilidade e risco nas margens da cidade: percepções e formas de ação de moradores de favelas cariocas. In: ROMPENDO o cerceamento da palavra: a voz dos favelados em busca de reconhecimento. Relatório de pesquisa Faperj. 2007a. [não publicado].

. Para além da metáfora da guerra: violência, cidadania, religião e ação coletiva no Rio de Janeiro. São Paulo: Attar Editorial, CNPqPronex, 2007b.

. Miedo y representación comunitaria en las favelas de Rio de Janeiro: los invisibles exilados de la violência. In: REGUILO, Rossana; GODOY, Marcial (Org.). Ciudades translocales: espacios, flujos, representación: perspectivas desde las Americas, Guadalajara: ITESO/Social Sciences Research Council, 2005.

. As mães em movimento. In: BIRMAN, Patrícia; LEITE, Márcia Pereira (Org.). Um mural para a dor: movimentos cívico-religiosos por justiça e paz. Porto Alegre: EdUFRGS, Pronex-MCT/CNPq, 2004.

LEITE, M. P.; MACHADO DA SILVA, L. A. Human rights, poverty and violence in the favelas of Rio de Janeiro. Document for the International Restitution Meeting, Small Grants Program for Research on Poverty and Human Right/UNESCO. Lisboa, 2007. [não publicado].

MACHADO DA SILVA, Luiz Antonio. Violência urbana, sociabilidade violenta e agenda pública. In: ROMPENDO o cerceamento da palavra: a voz dos favelados em busca de reconhecimento. Relatório de pesquisa Faperj. 2007. [não publicado].

. Sobre a violência hoje. Ciência e Saúde Coletiva, FIOCRUZ, v. 1, n. 2, 2006. 
MACHADO DA SILVA, Luiz Antonio. Sociabilidade violenta: por uma interpretação da criminalidade contemporânea no Brasil urbano. In: RIBEIRO, L. C. (Org.). Metrópoles: entre a cooperação e o conflito. São Paulo: Perseu Abramo, FASE, 2004a.

. Sociabilidade violenta: uma dificuldade a mais para a ação coletiva nas favelas. In: MACHADO DA SILVA et al. Rio: a democracia vista de baixo. Rio de Janeiro: IBASE, 2004b.

. Um problema na interpretação da criminalidade urbana violenta. Sociedade e Estado, Brasília, v. 10, n. 2, 1995.

. Violência e sociabilidade: tendências na atual conjuntura urbana no Brasil. In: RIBEIRO, L. C.; SANTOS Jr., O. (Org.). Globalização, fragmentação e reforma urbana: o futuro das cidades brasileiras na crise. Rio de Janeiro: Civilização Brasileira, 1994.

; Violência urbana: representação de uma ordem social. In: NASCIMENTO, E.; BARREIRA, I. (Org.). Brasil urbano: cenários da ordem e da desordem. Rio de Janeiro: Notrya, 1993.

. A política na favela. Cadernos de Estudos Brasileiros, v. 9, n. 41, 1967.

MACHADO DA SILVA, L. A.; LEITE, M. P. Favelas e democracia: temas e problemas da ação coletiva nas favelas cariocas. In: MACHADO DA SILVA et al., Rio: a democracia vista de baixo. Rio de Janeiro: IBASE, 2004.

MACHADO DA SILVA, L. A.; LEITE, M. P.; FRIDMAN, L. Matar, morrer, civilizar: o problema da segurança pública. In: MAPAS: Monitoramento Ativo da Participação da Sociedade. Rio de Janeiro: IBASE, Action Aid, Ford Foundation, 2005. 1 CDrom

MACHADO DA SILVA, L. A.; RIVERO, Patrícia. Polícia e crime violento nas favelas do Rio: percepções e efeitos sobre as rotinas dos moradores. Apresentado no $29^{\circ}$ Encontro Anual da ANPOCS, 2005. [não publicado]. 
MAFRA, Clara. Drogas e símbolos: redes de solidariedade em contextos de violência. In: ZALUAR, Alba; ALVITO, Marcos (Org.). Um século de favela. Rio de Janeiro: FGV, 1998.

MATTOS, Carla. Cultura de massa e neurose na terra do samba: um estudo sobre os processos de identificação em contextos de produção e recepção culturais. Dissertação (Mestrado em Ciências Sociais) - PPCIS/UERJ, 2006.

MESQUITA, Wânia. Tranqüilidade sob a ordem violenta: o controle social da 'mineira' em uma favela carioca. In: ROMPENDO o cerceamento da palavra: a voz dos favelados em busca de reconhecimento. Relatório de pesquisa Faperj. 2007. [não publicado].

MISSE, Michel. Malandros, marginais e vagabundos: acumulação social da violência no Rio de Janeiro. Tese (Doutorado em Sociologia) - IUPERJ, 1999.

. As ligações perigosas: mercado informal ilegal, narcotráfico e violência no Rio de Janeiro. Contemporaneidade e Educação, v. 2, n. $1,1997$.

MOORE Jr., Barrington. Injustiça: as bases sociais da obediência e da revolta. São Paulo: Brasiliense, 1987.

MORAES, Pedro Bodê de. Juventude, medo e violência. In: CICLO DE CONFERÊNCIAS DIREITO E PSICANÁLISE. Novos e invisiveis laços. 2005. [não publicado].

OLIVEIRA, Pedro Paulo. Sobre a adesão juvenil às redes de criminalidade em favelas. In: ROMPENDO o cerceamento da palavra: a voz dos favelados em busca de reconhecimento. Relatório de pesquisa Faperj. 2007. [não publicado].

PERALVA, Angelina. Violência e Democracia: o paradoxo brasileiro. Rio de Janeiro: Paz e Terra, 2000.

ROCHA, Lia de Mattos. Uma favela sem tráfico? Alcance e limites da ação do crime violento. In: ROMPENDO o cerceamento da palavra: a voz dos favelados em busca de reconhecimento. Relatório de pesquisa Faperj. 2007. [não publicado]. 
SOARES, Luiz Eduardo. Meu casaco de general: quinhentos dias no front da segurança pública do Rio de Janeiro. São Paulo: Companhia das Letras, 2000.

SOARES, L. E. et al. Violência e política no Rio de Janeiro. Rio de Janeiro: Relume Dumará, ISER, 1996.

VALLADARES, Lícia. A invenção da favela: do mito de origem a favela. com. Rio de Janeiro: FGV, 2005.

VENTURA, Zuenir. Cidade partida. São Paulo: Companhia das Letras, 1994.

VIVA RIO. Educação de jovens em situação de risco. Rio de Janeiro: Viva Rio, 2002. [não publicado].

WACQUANT, Loïc. As prisões da miséria. Rio de Janeiro: Jorge Zahar, 2001a.

. Os condenados da cidade: estudos sobre a marginalidade avançada. Rio de Janeiro: Revan, Observatório IPPUR/FASE, $2001 \mathrm{~b}$.

ZALUAR, Alba. Integração perversa: pobreza e tráfico de drogas. Rio de Janeiro: FGV, 2004.

. O medo e os movimentos sociais. Proposta, FASE, v. 23, n. 66, 1995.

. Condomínio do Diabo. Rio de Janeiro: Editora UFRJ, 1994.

. A máquina e a revolta. São Paulo: Brasiliense, 1985.

ZALUAR, Alba; ALVITO, Marcos (Org.). Um século de Favela. Rio de Janeiro: FGV, 1998. 